\title{
New Chromosome Counts in Five Alyssum Species from Turkey
}

\author{
Emrah Şirin*, Kuddisi Ertuğrul and Tuna Uysal \\ Department of Biology, Science Faculty, Selçuk University, Konya, Turkey
}

Received November 21, 2019; accepted December 23, 2019

\begin{abstract}
Summary Chromosome numbers of five Alyssum species (A. aizoides Boiss., A. aureum (Fenzl) Boiss., A. baumgartnerianum Bornm. ex Baumg. A. constellatum Boiss. and A. xanthocarpum Boiss.) from Turkey have been reported for the first time. A. aizoides and A. baumgartnerianum are tetraploid $(2 n=4 x=32)$ while $A$. aureum, A. constellatum and $A$. xanthocarpum are diploid $(2 n=2 x=16)$.
\end{abstract}

Keywords Alyssum, Brassicaceae, Chromosome number, Polyploid, Turkey.

Karyological data are of great importance when studying plant systematics and evolution, and are an effective tool used to establish the boundaries of the relationships between species (Stebbins 1971).

The main distribution areas of Brassicaceae are the Mediterranean, Irano-Turanian and Saharo-Sindian regions (Hedge 1976). Turkey having 653 native species belonging to 61 genera is one of the richest countries in terms of their abundance (Al-Shehbaz et al. 2007). In the Brassicaceae family, chromosome numbers are known for 232 of the 338 genera (68.6\%) and 1559 of the 3709 species (42\%). The basic numbers vary from 4 to 13 , however, $x=8$ has a surprisingly high percentage (37\%) (Warwick et al. 2006).

Alyssum is one of the largest genera with approximately 230 species in Brassicaceae and its main distribution areas are Eastern Europe and Turkey (Al-Shehbaz and Beilstein 2006). This genus is the largest among genera in Flora of Turkey and is represented by 90 species. Of these species, 54 are endemic and approximately one-third of these are endangered and require preservation (Babaoğlu et al. 2004).

The aims of the present study are to reveal the chromosome numbers of Alyssum species and investigate the degree of chromosomal variation of the studied at the interspecies level.

\section{Materials and methods}

The studied Alyssum samples were collected at least 10 individuals of each species from various localities in Turkey in 2018 (Table 1). Mature seeds were selected and periodically germinated for chromosome analysis. About the five seedlings were investigated in each individual. Vouchers are stored in Herbarium of Science Faculty, Selçuk University (KNYA) or the collection of E. Şirin. Chromosome counts were carried out during the somatic metaphase using a squashing technique. Root meristems obtained from the germinated seeds were used. The samples were pre-treated with a $2 \mathrm{mM}$ 8-hydroxyquinoline for $8 \mathrm{~h}$ at $4^{\circ} \mathrm{C}$ and then fixed for $24 \mathrm{~h}$ at $4^{\circ} \mathrm{C}$ using Carnoy fixative. Before the staining process, the material was hydrolyzed for 20 min using $5 \mathrm{M}$ $\mathrm{HCl}$ at room temperature. The samples were then stained with $1 \%$ aceto-orcein and placed in $45 \%$ acetic acid. At least 10 metaphases were examined for each plant of species. The best metaphase image was recorded using an Olympus DP-72 digital camera attached to an Olympus BX53 microscope.

Table 1. Localities of the Alyssum taxa.

\begin{tabular}{|c|c|c|}
\hline Species & Locality, altitude and collection date & Voucher \\
\hline A. aizoides & Antalya: Geyik Mountain, 2300 m, 24.07.2018 & EŞ-766 (KNYA) \\
\hline A. aureum & Konya: Çumra, $980 \mathrm{~m}, 25.07 .2018$ & EŞ-768-HG (KNYA) \\
\hline A. baumgartnerianum & Karaman: Yelibel Mountain, 2000 m, 24.07.2018 & EŞ-767-HG (KNYA) \\
\hline A. constellatum & Burdur: Tefenni, $1100 \mathrm{~m}, 25.07 .2018$ & EŞ-769-HG (KNYA) \\
\hline A. xanthocarpum & Kastamonu: Ilgaz Mountain, $1550 \mathrm{~m}, 26.07 .2018$ & EŞ-770 (KNYA) \\
\hline
\end{tabular}

\footnotetext{
*Corresponding author, e-mail: emrahsirin@selcuk.edu.tr

DOI: $10.1508 /$ cytologia. 85.127
} 

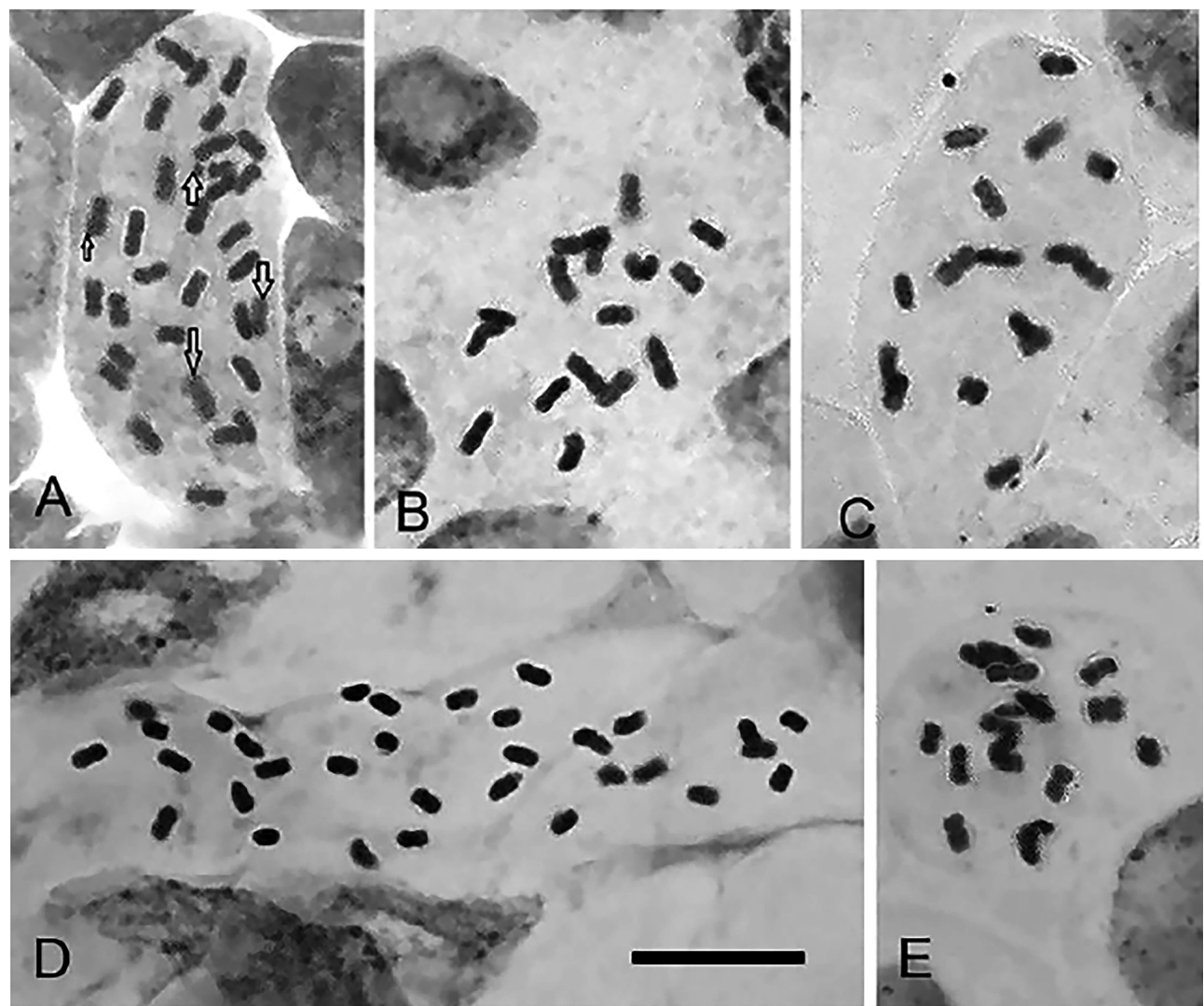

Fig. 1. The mitotic metaphase chromosomes of studied taxa. (A) A. aizoides, (B) A. aureum, (C) A. baumgartnerianum, (D) A. constellatum, and (E) A. xanthocarpum. Arrows indicate satellites. Scale bar $=10 \mu \mathrm{m}$.

Table 2. Chromosome numbers reported in Alyssum taxa.

\begin{tabular}{|c|c|c|}
\hline Taxa & Chromosome number & References \\
\hline A. aizoides & $2 n=4 x=32$ & Present study \\
\hline A. argyrophyllum & $2 n=16$ & Contandriopoulos and Afzal-Rafii (1973) \\
\hline A. aurantiacum & $2 n=16$ & Strid (1987) \\
\hline A. aureum & $2 n=16$ & Present study \\
\hline A. baumgartnerianum & $2 n=4 x=32$ & Present study \\
\hline A. bornmuelleri & $2 n=16$ & Contandriopoulos and Afzal-Rafii (1973) \\
\hline A. borzaeanum & $2 n=4 x=32$ & Contandriopoulos and Afzal-Rafii (1973) \\
\hline A. callichroum & $2 n=6 x=48$ & Contandriopoulos and Afzal-Rafii (1973) \\
\hline A. cassium & $2 n=4 x=32$ & Contandriopoulos and Afzal-Rafii (1973) \\
\hline A. cilicicum & $2 n=16$ & Contandriopoulos and Afzal-Rafii (1973) \\
\hline A. condensatum subsp. condensatum & $2 n=16$ & Contandriopoulos and Afzal-Rafii (1973) \\
\hline A. condensatum subsp. flexible & $2 n=16$ & Contandriopoulos and Afzal-Rafii (1973) \\
\hline A. constellatum & $2 n=16$ & Present study \\
\hline A. contemptum & $2 n=16$ & Contandriopoulos and Afzal-Rafii (1973) \\
\hline A. corsicum & $2 n=16$ & Contandriopoulos and Afzal-Rafii (1973) \\
\hline A. desertorum & $2 n=16$ & Contandriopoulos and Afzal-Rafii (1973) \\
\hline A. erosulum & $2 n=16$ & Contandriopoulos and Afzal-Rafii (1973) \\
\hline A. floribundum & $2 n=16$ & Contandriopoulos and Afzal-Rafii (1973) \\
\hline A. giosnanum & $2 n=4 x=32$ & Contandriopoulos and Afzal-Rafii (1973) \\
\hline A. huber-morathii & $2 n=16$ & Contandriopoulos and Afzal-Rafii (1973) \\
\hline A. huetii & $2 n=14$ & Ancev et al. (1998) \\
\hline A. lepidoto-stellatum & $2 n=4 x=32$ & Contandriopoulos and Afzal-Rafii (1973) \\
\hline A. masmenaeum & $2 n=16$ & Contandriopoulos and Afzal-Rafii (1973) \\
\hline A. meniocoides & $2 n=14$ & Ancev et al. (1998) \\
\hline A. minutum & $2 n=16$ & Aryavand (1975) \\
\hline A. mouradicum & $2 n=16$ & Contandriopoulos and Afzal-Rafii (1973) \\
\hline A. oxycarpum & $2 n=16$ & Contandriopoulos and Afzal-Rafii (1973) \\
\hline A. pateri & $2 n=4 x=32$ & Contandriopoulos and Afzal-Rafii (1973) \\
\hline A. praecox & $2 n=4 x=32$ & Contandriopoulos and Afzal-Rafii (1973) \\
\hline A. stapfii & $2 n=6 x=48$ & Aryavand (1975) \\
\hline A. strigosum & $2 n=16$ & Contandriopoulos and Afzal-Rafii (1973) \\
\hline A. umbellatum & $2 n=14$ & Strid (1987) \\
\hline A. xanthocarpum & $2 n=16$ & Present study \\
\hline
\end{tabular}


Results and discussion

The chromosome set of $A$. aizoides was composed of 32 chromosomes (Fig. 1A). The chromosome number was reported for the first time. This endemic species is different from the others because of having satellites. In $A$. aureum the chromosome number was determined to be $2 n=16$ (Fig. 1B). Our report is the first chromosome study for this species. In A. baumgartnerianum the chromosome number was determined to be $2 n=4 x=32$ (Fig. 1C). The chromosome number of this species was reported for the first time here. In A. constellatum the chromosome number was determined to be $2 n=16$ (Fig. 1D). Our report is the first chromosome study for this species. The chromosome set of A. xanthocarpum comprised of 16 chromosomes (Fig. 1E).

The chromosome number is an important parameter used to explain the phylogenetic relationships observed among species (Eroğlu et al. 2013, Uysal et al. 2017). In the Brassicaceae family, the chromosome numbers are significantly different among the taxa in the genera and this is of importance for the evolutional and systematic evaluation of the family (Karaismailoğlu 2018).

The basic chromosome count for the Alysseae species is $x=8$ (Warwick et al. 2008, Rešetnik et al. 2013). Alysseae species contains 24 genera and 277 taxa, and the polyploid levels were determined for 171 of these taxa (Marhold and Lihová 2006). Of these, 95 (55.6\%) were diploids, 43 (25.1\%) were polyploids and 33 (19.3\%) were diploid-polyploids. Both polyploids and aneuploids play an important role in the evolution of Brassicaceae (Marhold and Lihová 2006). The most common chromosome count in this genus was $x=8$, while $x=7$ is less common (Table 2). Higher chromosome counts may represent a more primitive state (Lysak and Lexer 2006). In this study, all taxa have the basic $x=8$ chromosome number. Also, three of the taxa have diploid chromosomes, whereas $A$. aizoides and $A$. baumgartnerianum are tetraploid and also $A$. aizoides is different from the others because of having satellites. Karyological observations in our study might contribute to the differentiation of Turkish Alyssum taxa.

\section{Acknowledgements}

This work was supported by the Scientific Investigation Project Coordinator of Selçuk University (Project No: 18401090).

\section{References}

Al-Shehbaz, I. A., Beilstein, M. A. and Kellogg, E. A. 2006. Systematic and phylogeny of the Brassicaceae (Cruciferae): An overwiew. Plant Syst. Evol. 56: 89-120.

Al-Shehbaz, I. A., Mutlu, B. and Dönmez, A. A. 2007. The Brassicaceae (Cruciferae) of Turkey. Turk. J. Bot. 31: 327-336.

Ancev, M. E., Orcan, N. and Goranova, V. 1998. In: Kamari, G., Felder, F. and Garbari, F. (eds.). Mediterranean Chromosome Number Reports (968-969). Flora Medit. 8: 213-313.

Aryavand, A. 1975. Contribution à l'étude cytotaxonomique de quelques Crucifères de l'Iran et de la Turquie. Bull. Soc. Neuchâteloise Sci. Nat. 98: 43-58.

Babaoğlu, S., Açık, L., Çelebi, A. and Adıgüzel, N. 2004. Molecular analysis using RAPD-PCR and SDS-PAGE in aome species of Turkish Alyssum L. (Brassicaceae). G.Ü. Fen Bilimleri Dergisi 17: 25-33. (in Turkish)

Contandriopoulos, J. and Afzal-Rafii, Z. 1973. Contribution à l'étude cytotaxonomique des Alyssum de Turquie. Ber. Schweiz Bot. Ges. 83: 14-29.

Eroğlu, H. E., Şimşek, N., Koç, M. and Hamzaoğlu, E. 2013. Karyotype analysis of some Minuartia L. (Caryophyllaceae) taxa. Plant Syst. Evol. 299: 67-73.

Hedge, I. C. 1976. A Systematic and Geographical Survey of the Old World Cruciferae. In: Vaughan, J. G., Macleod, A. J and Jones, B. M. G. (eds.). The Biology and Chemistry of the Cruciferae. Academic Press, London/New York/San Francisco. pp. 1-45.

Karaismailoğlu, M. C. 2018. Comparison of the karyotype analyses of two Aethionema speciosum subspecies from Turkey. Caryologia 71: 128-132.

Lysak, M. A. and Lexer, C. 2006. Towards the era of comparative evolutionary genomics in Brassicaceae. Plant Syst. Evol. 259: 175-198.

Marhold, K. and Lihová, J. 2006. Polyploidy, hybridization and reticulate evolution: Lessons from the Brassicaceae. Plant Syst. Evol. 259: 143-174.

Rešetnik, I., Šatović, Z., Schneeweiss, G. M. and Liber, Z. 2013. Phylogenetic relationships in Brassicaceae tribe Alysseae inferred from nuclear ribosomal and chloroplast DNA sequence data. Mol. Phylogenet. Evol. 69: 772-786.

Stebbins, G. L. 1971. Chromosomal Evolution in Higher Plants. Edward Arnold Ltd., London.

Strid, A. 1987. Chromosome numbers of Turkish mountain plants. An annotated list of 34 taxa. Notes R. Bot. Gard. Edinb. 44: 351-356.

Uysal, T., Bozkurt, M., Tugay, O., Ertuğrul, K., Şimşek Sezer, E. and Köse, Y. 2017. Karyomorphology of Turkish species in Centaurea sections Centaurea and Phalolepis (Asteraceae) and implications for taxonomy. Plant Biosyst. 151: 949-964.

Warwick, S. I. and Al-Shehbaz, I. A. 2006. Brassicaceae: chromosome number index and database on CD-Rom. Plant Syst. Evol. 259: $237-248$.

Warwick, S. I., Sauder, C. A. and A1-Shehbaz, I. A. 2008. Phylogenetic relationships in the tribe Alysseae (Brassicaceae) based on nuclear ribosomal ITS DNA sequences. Can. J. Bot. 86: 315-336. 